\title{
Canopy Gap Phase Regeneration: A Study in Moist Temperate Forests of Central Himalayas, India
}

\author{
Shalini Dhyani ${ }^{1,2 *}$, R K Maikhuri², K S Rao ${ }^{3}$ \\ ${ }^{1}$ National Environmental Engineering Research Institute (CSIR-NEERI), Nehru Marg, Nagpur India (Current \\ Organisation), shalini3006@gmail.com \\ ${ }^{2}$ G. B. Pant Institute of Himalayan Environment and Development, Garhwal Unit, Srinagar Garhwal, Uttarakhand 246 \\ 174, India (Work done at) \\ ${ }^{3}$ Department of Botany, University of Delhi, Delhi, India.
}

\begin{abstract}
Broad leaved forests continuously have some asynchronous and localized disturbance events. Tree fall gaps are the dominant form of such disturbances in these forests. Moist temperate forests dominated by Quercus leucotricophora in Garhwal were investigated for study. Ten random transect belts were established in a mixed broadleaved forest patch. The forest comprised of gaps, created by various natural processes. Gaps varied in size ranging from 48 to $589 \mathrm{~m} 2$. Microclimatic and edaphic variables of canopy gap and understorey areas were recorded to assess the parameters that influence gap phase regeneration. Forests of the studyarea comprised of gaps that varied in size and shape. Light intensity, soil moisture and soil temperature were prime micro-climatic variables influencing species recruitment in gaps.Species assemblage was recorded higher from gaps than forest understorey (20 and 17 tree species, respectively). Overall recruitment of tree species in understorey and canopy gaps was 3054 seedling ha-1 and 2277 saplings ha-1, respectively. The results obtained during our study show that gap formation process in moist temperate forests of Garhwal promotes a strong but temporary variations in microclimatic environment. This heterogeneity factor determines the biological diversity but needs more long term systematic research in Garhwal for better understanding. Keywords: Forest Disturbance; Gap Phase Regeneration; Garhwal Himalaya; Moist Temperate Forests.
\end{abstract}

\section{Introduction}

Both natural and artificial disturbances in a forest can cause tree death or injury, which in turn creates openings in the forest cover known as canopy gaps (Yamamoto 2000). Canopy gap formation, a frequent small-scale disturbance in many forests, has been hypothesized to be an important event in the structuring of many forest communities. These gaps are often filled with other trees, and this replacement phenomenon is termed gap dynamics (Brokaw and Busing 2000). Canopy disturbances influence structure and composition of forest communities, because gaps created by disturbances influence germination, growth and survival of tree seedlings (Major et al. 2013). Forest disturbances of various spatial extents and magnitude shape composition, structure and stand development patterns (Ou \& Su, 2012; Richard and Hart, 2011; McCarthy 2001). Disturbance often exist along a continuum spanning from broad scale, stand replacing events where most of the overstory is removed to fine scale events resulting from the removal of single canopy individuals or small cluster of trees (Oliver and Larson, 1996). These gaps play an important role in forest ecology by helping to maintain bio and pedo-diversity, influencing nutrient cycling and preserving the uneven age nature of late successional forests. Canopy gaps increase environmental heterogeneity (Brokaw 1985, Denslow 1987), by altering abundances and distributions of abiotic and biotic resources. Resources that have been demonstrated to change after gap formation are light (Chazdon and Fetcher 1984), soil moisture, nutrients (Uhl et al. 1988), seed availability (Alvarez-Buylla and Garc1 'a-Barrios 1991), seed germination (Murray 1988) and herbivores (Braker and Chazdon 1992). Such spatial and 
temporal changes in resource heterogeneity may affect forest dynamics thereby linking natural disturbances to the maintenance of plant species diversity.

In temperate forests wind throw often creates canopy gaps which can dramatically change the microclimate and soil water balance (Yamamoto, 1995). Change in microclimate strongly influences the process of regeneration and biodiversity within forest ecosystems. Change in microclimatic variables and light in the gap area, alters germination and growing conditions in canopy gaps. The prospective composition of forests depends on potential regenerative status of tree species within a forest stand (Henle et al. 2004), therefore, an understanding of the processes that affect regeneration of forest species is of significant importance to both ecologists and forest managers. Regeneration pattern may be similar or dissimilar to pre-disturbance levels in gaps (Slik et al. 2003). Understanding microclimatic conditions in canopy gaps and it's impact on species recruitment is a prerequisite in developing and improving techniques for forest management and conservation practices. However, information is very scarce on how precisely gap opening affects the microclimates within canopy gaps and beneath surrounding tree canopies and how the spatial distribution of gaps influences microclimates across entire forest stands.

Predicting tree seedling recruitment after disturbance through an understanding of forest dynamics and succession is vital and fundamental in managing forests (Coates 2002). This task has immense importance for Garhwal, where forests are one of the most vital resources of the state, where forest research has generated comparatively little evidence on gap dynamics. Most regeneration research in forest of Garhwal has focused on natural course of regeneration and tree species recruitment in dry and moist temperate forests, while canopy gap phase regeneration has received less attention and therefore are poorly documented. The study aims to understand gap phase regeneration in moist temperate forest with mixed broad leaved tree species. The specific objectives were to (a); to determine whether specific difference exists between the species regenerating in canopy gaps and adjacent understory- are the mixed broad leaved moist temperate forests compositionally stable or in successional sequences? and (b) to determine the influence of some important microclimatic parameters on regeneration of gap filler tree species.

\section{Material and Methods}

\subsection{Study area}

The study was conducted in moist temperate mixed broad-leaved forests of Upper Kedarnath Valley $\left(30^{\circ} 25^{\prime}-30^{\circ}\right.$ $45^{\prime} \mathrm{N}$ latitude, $78^{0} 55^{\prime}-79^{\circ} 22^{\prime} \mathrm{E}$ ) in Garhwal part of Uttarakhand. The identified study sites fall in one of the areas of lesser Himalayan geographic province. Study area considered during was located at an altitudinal gradient of 1700 to $2800 \mathrm{~m}$ amsl. These forests are one of the very rich moist temperate forest patches of Garhwal and were chosen since they are the most representative temperate forests in Uttarakhand. Mild levels of anthropogenic disturbances (e.g. fuel wood, fodder and litter collection) occur in a uniform pattern across some portions of the forested region (Misra et al. 2009), but no major disturbances have been recorded. Quercus leucotricophora is the dominant tree species of the patch and Rhododendron arboretum, Lyonia ovalifolia, Pyrus pashia etc. as major associate tree species. The floristic richness of the area can be attributed to its location at the junction of Sino-Indian biogeographic regions (Dinerstein 1997; Prabhakar et al. 2006) (Figure 1). The entire area has rugged topography with numerous steep hills and narrow valleys and constitutes the catchment of Alaknanda the major tributary of river Ganga. The metamorphic rock consists of gneisses, granites and schists while, soil comprises of clay loam texture and is fairly acidic (pH-6) (Misra 2009). The geneisses, schists and granites has given rise to a light, micaceous soil that is rich, deep and excellent for tree growth on favourable aspects.

\subsection{Sampling}

Natural course of tree species recruitment and gap phase performance of tree species was studied in a vast patch of mixed broadleaved forest in Garhwal Himalaya. The study site comprised mixed broad leaved forest patch of multilayered canopy. Patch of forest considered for gap study was selected on the basis of it's canopy cover, accessibility (as most of the undisturbed forests in Garhwal can only be found far from road head and human habitations), no human interference for biomass extraction from the forest stand etc. Gap surface was measured in 
percentage with Abney's level. Two measures of slope were taken from opposite sides of the gap maker that were later averaged. We systematically sampled canopy gaps located entirely or partially in ten vegetation transects in mixed oak

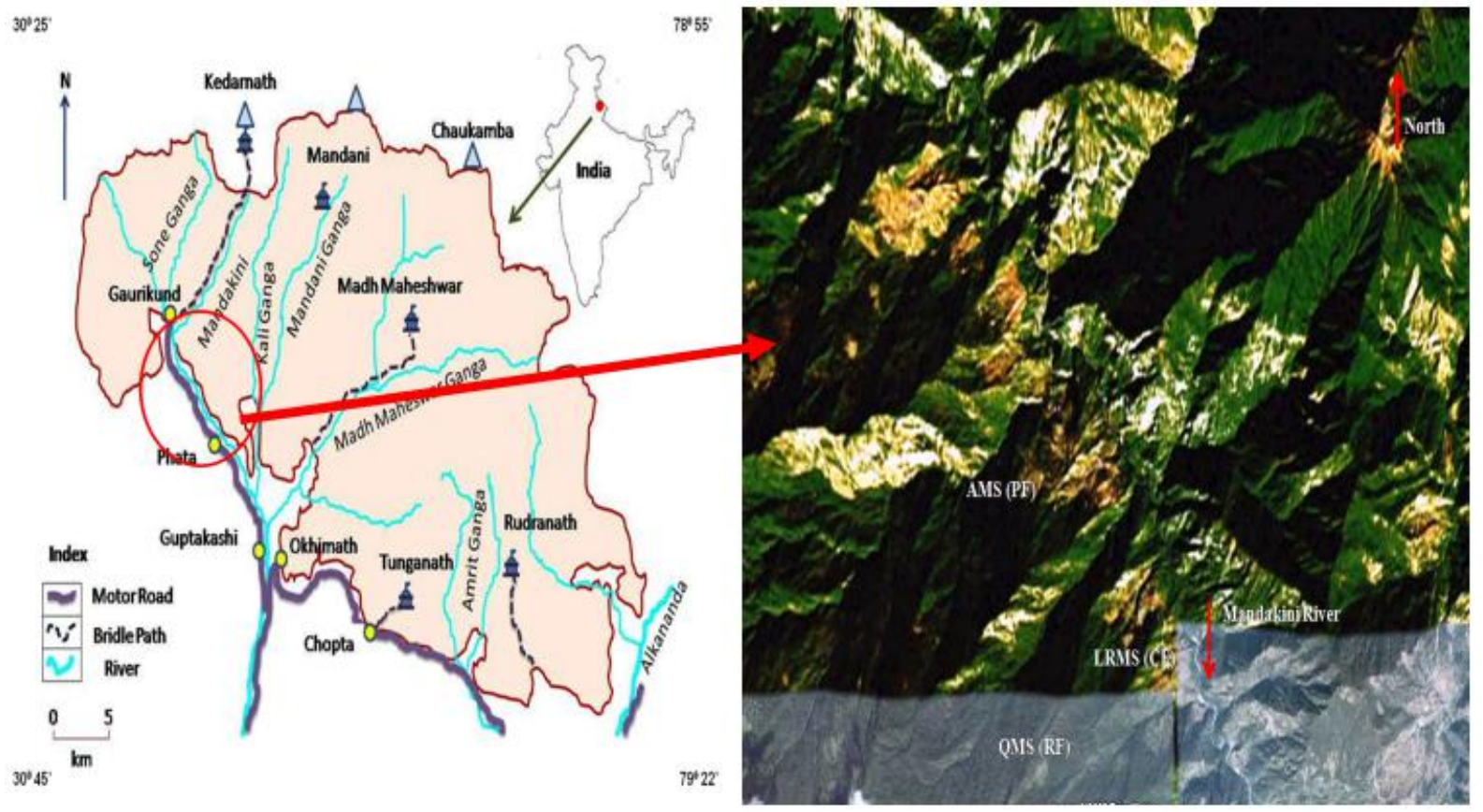

Figure 1; Location map of the study area. A view of the study area showing major studied forest stands. (Source: Google Earth). forest patch. The transects were spaced at $200 \mathrm{~m}$ intervals and were $20 \mathrm{~m}$ wide. Within the transects gaps were considered as and where they occurred. A gap was considered as an opening in the forest canopy extending through all foliage levels to an average height of $2 \mathrm{~m}$ above ground (Brokaw 1985). Once the gap limits were established the next step was to calculate gap area. The Gap area was calculated by "triangles" method (Lima 2005). During fieldwork, distances were measured between the consecutive corners (the sides of the projected polygon) and between non-consecutive corners (the diagonals of the polygon). Thus, each triangle area was calculated by fitting its sides to the following Heron's formula:

$$
A=\sqrt{ }[p(p-a)(p-b)(p-c)]
$$

Total gap area was then obtained by summing the area of all the triangles used to fit the polygon. Gaps were later categorized into small $\left(<50 \mathrm{~m}^{2}\right)$, medium $\left(50-100 \mathrm{~m}^{2}\right)$, large $\left(100-250 \mathrm{~m}^{2}\right)$ and very large $\left(>250 \mathrm{~m}^{2}\right)$ sized gaps based on their area. After a gap forms, increased solar radiation allows vegetation to grow quickly. Overtime, microsite characteristics within the gap slowly reverts to those of a closed forest. The gap age was calculated from degree of decomposition of the gap maker, as we do not had very old gaps for our study we followed Liu and Hytteborn, 1991 method. Each gap was classified into new ( $<3$ years old) and old gaps ( $>3$ years old) based on the indicators and visible characters of the gap maker species for e.g. Whorl count method (Runkle, 1982) by studying the spacing in branch whorls of the tree growing in gap area also helped to tentatively identify gap age.

The regenerating individuals were categorized into saplings (individuals with $>20 \mathrm{~cm}$ height and CBH 10.5-31.4 $\mathrm{cm}$ ) and seedlings (individuals $<20 \mathrm{~cm}$ height $\mathrm{CBH}<10.5 \mathrm{~cm}$ ) (Deb and Sundriyal 2007). The quadrat size was $5 \times 5 \mathrm{~m}$ for sapling analysis $(n=100)$ and $2 \times 2 \mathrm{~m}$ for seedlings analysis $(\mathrm{n}=125)$. Specimens of all plant species were collected and identified to species level. The species composition and density of regenerating saplings and seedlings were recorded from the gaps. Climatic and edaphic variables were assessed to study difference in micro environment of canopy gap and non gap areas. Climatic variables were air temperatures, relative humidity and light intensity. Edaphic variables were soil temperature, litter depth, soil moisture, water holding capacity, and $\mathrm{pH}$. Climatic and edaphic category variables of gap and non gap were measured at the centre of the gaps and at three points of non gap within 5-10 m from the gap edge at $1200 \mathrm{hrs}$. Air temperature and relative humidity were measured at ground level using 
humidity temperature meter (Hucer Soil Hygrometer, Germany-412CTH). Light intensity (photon flux density) was measured at ground level using a lux meter (LX-CHY-332). Soil temperature was estimated by soil muti-thermometer, soil litter thickness was estimated by a hand held measuring scale, soil moisture content was estimated by gravimetric method, soil water holding capacity (Veihmeyer and Hendrickson 1931) and soil pH was estimated by using century digital portable $\mathrm{pH}$ meter.

\subsection{Data analysis}

The descriptive statistical analysis was performed to give mean values for the microclimatic parameters of gaps and non gap areas. Kendall correlation coefficient was used to establish a relationship between recruitment of tree species (saplings and seedlings) and microclimatic variations of gap and non gap areas. Cluster analysis was applied to the species composition of regenerating tree species in gap and non gap areas. The Sorensen (Bray-Curtis) index and group average linkage method were used to calculate species groupings (MecCune \& Mefford 1999). Density of the tree seedlings indicating regeneration in gaps and non gaps (understorey) was analysed using Cluster Analysis (CA) (Pielou 1984). Canonical Correspondence Analysis (CCA) (Ter Braak 1987) is a type of direct ordination method and was explicitly used to analyze the relationship between species occurrence patterns and their underlying environmental gradients in gap and non gap areas. CCA is an ordination technique, which relies on normality assumptions. All multivariate analyses were conducted using PC ord (version 4.5) (MecCune and Mefford 1999) while, descriptive statistics was conducted using Microsoft Excel (version 2007) and Correlation analysis was carried out using Minitab version 12 .

\section{Results}

\subsection{Causes of gap formation, gap makers, and size and shapes of gaps and stand characteristics}

Study area exhibits temperate climate having typical rainfall pattern with rainy season extending from May to September. At times the rainy season prolongs to 9 months in a year. Occasional off-season showers are common.Study area has temperature with a minimum of $-2^{\circ} \mathrm{C}$ in winters (December) to a maximum of $30^{\circ} \mathrm{C}$ in summers (June). Relative humidity of the area is high throughout the year.

A total of 30 gaps were identified and investigated in detail (Table 1). It was observed that gaps were created mainly due to branch fall, crown fall, standing dead trees and tree fall. Gap size varied from 48-589 $\mathrm{m}^{2}$. Majority of gaps were created during rainy season as compared to dry winter season, though snow fall and occasional hail storms were also are responsible for development of canopy gaps.

All canopy gaps were located at a slope except for 7 gaps which were located at almost flat surface. Small sized gaps ( ize $<50 \mathrm{~m}^{2}$ to $>25 \mathrm{~m}^{2}$ ) accounted for $3.33 \%$ of total gaps, medium sized gaps (size 50-100 $\mathrm{m}^{2}$ ) $33.33 \%$; large sized gaps (size 100-250 $\mathrm{m}^{2}$ ) $33.33 \%$ and large sized gaps (size $>250 \mathrm{~m}^{2}$ ) accounted for $30 \%$ of total gaps. The shape of the gaps was not homogeneous. It varied from dumbbell to hexagonal, to elliptical, to multiangular.

\subsection{Gap makers}

Majority of gaps were formed due to single or multiple branch falls that accounted for $50 \%$ of the gap formation; single tree fall accounted for $30 \%$ of the gap formation and multiple tree fall for $20 \%$ of the gap formation. Quercus leucotrichophora was the major gap creator tree species whereas, Lyonia ovalifolia, Neolitsea pallens, Abies pindrow, Quercus floribunda, Alnus nepalensis and Aesculus indica were other forest tree species that created gaps. The age of the gaps varied from 1 to $>8-9$ years. The microsite heterogeneity of the gap areas comprised of broken stumps and branches, wood debris, logs and snags, soil moulds etc. Downed wood/logs $(76 \%)$ was more prevalent than the snags (24\%) [that includes all gap makers standing dead (17\%) and gap makers standing dead with their crown snapped $(7 \%)$ ] (Table 1). Also, the number of gap makers was very low in few gaps probably because some gap creators were dead and the organic matter rapidly covered the downed wood.

\subsection{Microenvironment in gaps and nearby non gap areas}

The light intensity in the gaps (range 535.56 $\pm 74.77-880 \pm 0$ lux) was recorded significantly higher comparable to the understorey of adjacent intact forest understorey $(245.67 \pm 13.50$ lux $)$ areas. The mean air temperature in the gaps 
was recorded higher from large sized gaps (range $17.2 \pm 0.92-22.25 \pm 1.14{ }^{\circ} \mathrm{C}$ ) than forest understorey $\left(20.05 \pm 0.56^{\circ} \mathrm{C}\right.$ ). Air temperature was recorded higher in understorey areas than canopy gap areas. Among different gap sizes air

\begin{tabular}{|c|c|c|c|c|c|c|}
\hline Gap No. & $\begin{array}{l}\text { Area } \\
\left(m^{2}\right)\end{array}$ & $\begin{array}{l}\text { No. of } \\
\text { tree fall }\end{array}$ & $\begin{array}{l}\text { Cause of } \\
\text { gap } \\
\text { formation }\end{array}$ & Gap maker species & Topography & $\begin{array}{l}\text { Microsite } \\
\text { heterogeneity }\end{array}$ \\
\hline 1 & 79.65 & Nil & Branch fall & Quercus leucotrichophora & Gentle slope & $\begin{array}{l}\text { Broken branches, } \\
\text { decaying snag }\end{array}$ \\
\hline 2 & 63.46 & Nil & Branch fall & Quercus leucotrichophora & Gentle slope & $\begin{array}{l}\text { Broken branches, } \\
\text { decaying snag }\end{array}$ \\
\hline 3 & 574.83 & Nil & Branch fall & $\begin{array}{l}\text { Quercus leucotrichophora, } \\
\text { Lyonia ovalifolia }\end{array}$ & Gentle slope & Decaying logs \\
\hline 4 & 101.67 & Nil & Branch fall & Quercus leucotrichophora & Gentle slope & Branches, debris \\
\hline 5 & 312.99 & Nil & Branch fall & Quercus leucotrichophora & Gentle slope & Decaying logs \\
\hline 6 & 53.67 & Nil & Branch fall & Lyonia ovalifolia & Gentle slope & Decaying logs \\
\hline 7 & 169.67 & Nil & Branch fall & Quercus leucotrichophora & Level Surface & Decaying logs \\
\hline 8 & 90.68 & Nil & Branch fall & Quercus floribunda & Level Surface & Decaying logs \\
\hline 9 & 48.43 & Single & Tree fall & Lyonia ovalifolia & Gentle slope & $\begin{array}{l}\text { Old debris, } \\
\text { Decaying logs }\end{array}$ \\
\hline 10 & 166.56 & Multiple & Tree fall & $\begin{array}{l}\text { Lyonia ovalifolia, Alnus } \\
\text { nepalensis }\end{array}$ & Gentle slope & $\begin{array}{l}\text { Old debris, } \\
\text { Decaying logs }\end{array}$ \\
\hline 11 & 79.65 & Single & Tree fall & Carpinus viminea & Level Surface & $\begin{array}{l}\text { Old debris, } \\
\text { Decaying logs }\end{array}$ \\
\hline 12 & 63.14 & Nil & Branch fall & Aesculus indica & Gentle slope & $\begin{array}{l}\text { Old debris, } \\
\text { Decaying logs }\end{array}$ \\
\hline 13 & 574.84 & Single & Tree fall & Aesculus indica & Gentle slope & $\begin{array}{l}\text { Decaying logs } \\
\text { and snags }\end{array}$ \\
\hline 14 & 101.68 & Single & Tree fall & Acer caesium & Gentle slope & $\begin{array}{l}\text { Old debris, } \\
\text { Decaying logs }\end{array}$ \\
\hline 15 & 313.01 & Nil & Branch fall & Alnus nepalensis & Gentle slope & Broken branches \\
\hline 16 & 552.45 & Multiple & Tree fall & $\begin{array}{l}\text { Symplocos paniculata, } \\
\text { Carpinus viminea }\end{array}$ & Gentle slope & $\begin{array}{l}\text { Decaying logs } \\
\text { and snags }\end{array}$ \\
\hline 17 & 162.55 & Nil & Branch fall & $\begin{array}{l}\text { Aesculus indica, Neolitsea } \\
\text { pallens }\end{array}$ & Gentle slope & Debris \\
\hline 18 & 269.23 & Multiple & Tree fall & Neolitsea pallens & Level Surface & Very old debris \\
\hline 19 & 81.97 & Single & Tree fall & $\begin{array}{l}\text { Quercus leucotrichophora } \\
\text { Fraxinus micrantha }\end{array}$ & Gentle slope & Very old debris \\
\hline 20 & 248.62 & Multiple & Tree fall & $\begin{array}{l}\text { Lyonia ovalifolia, } \\
\text { Rhododendron arboreum }\end{array}$ & Gentle slope & $\begin{array}{l}\text { Decaying logs } \\
\text { and snags }\end{array}$ \\
\hline
\end{tabular}

Table 1. Physical features and microsite heterogeneity of the tree fall gaps in the mixed broadleaved forest of Kedarnath Wildlife Sanctuary

temperature was recorded highest from large sized gaps $\left(22.25 \pm 1.14{ }^{\circ} \mathrm{C}\right)$. Relative humidity was recorded significantly higher $(67.35 \pm 1.19 \%)$ from understorey areas compared to gaps (range $60.40 \pm 2.13$ to $64.56 \pm 2.15 \%$ ). Soil temperature in the gaps $\left(1.74 \pm 0.04\right.$ to $\left.1.86 \pm 0.04{ }^{\circ} \mathrm{C}\right)$ was recorded higher than understorey $\left(1.70 \pm 0.03{ }^{\circ} \mathrm{C}\right)$. Litter depth varied from $2.15 \pm 0.17$ to $3.13 \pm 0 \mathrm{~cm}$ in gaps and was comparatively lower than litter depth recorded from understorey $(3.20 \pm 0.20$ $\mathrm{cm})$ areas. Mean soil moisture percentage was reported lower from small sized gaps and higher from the large sized gaps (range $24.7 \pm 0-31.87 \pm 3.95 \%$ ) than non gap (27.23 $\pm 1.24 \%$ ) areas (Table 2).

Size of gaps showed positive correlation with litter depth $(r=0.173, p<0.05)$, relative humidity $(r=0.192, p<0.05)$ and negative correlation with soil moisture $(\mathrm{r}=-0.0169, \mathrm{p}<0.05)$. In forest understorey, relative humidity showed positive correlation with soil temperature $(\mathrm{r}=0.346, \mathrm{p}<0.05)$, litter depth $(\mathrm{r}=0.246, \mathrm{p}<0.05)$ and soil moisture $(\mathrm{r}=$ $0.188, p<0.05)$. Air temperature showed positive correlation with soil temperature $(r=0.0795, p<0.05)$, litter depth $(r=$ $0.141, \mathrm{p}<0.05)$ and soil moisture $(\mathrm{r}=0.302, \mathrm{p}<0.05)$ whereas, litter depth had positive correlation with soil moisture $(\mathrm{r}=$ $0.31, \mathrm{p}<0.05)$. Additionally correlations received were weak positive and negative correlations. 


\subsection{Tree regeneration in canopy gaps and understorey/non gaps}

The total density of the twenty regenerating species in the gaps was observed 2277 seedling s ha ${ }^{-1}$. Five tree species belonging to top canopy of the forest were found regenerating in the gaps. Cinnamomum tamala with a density

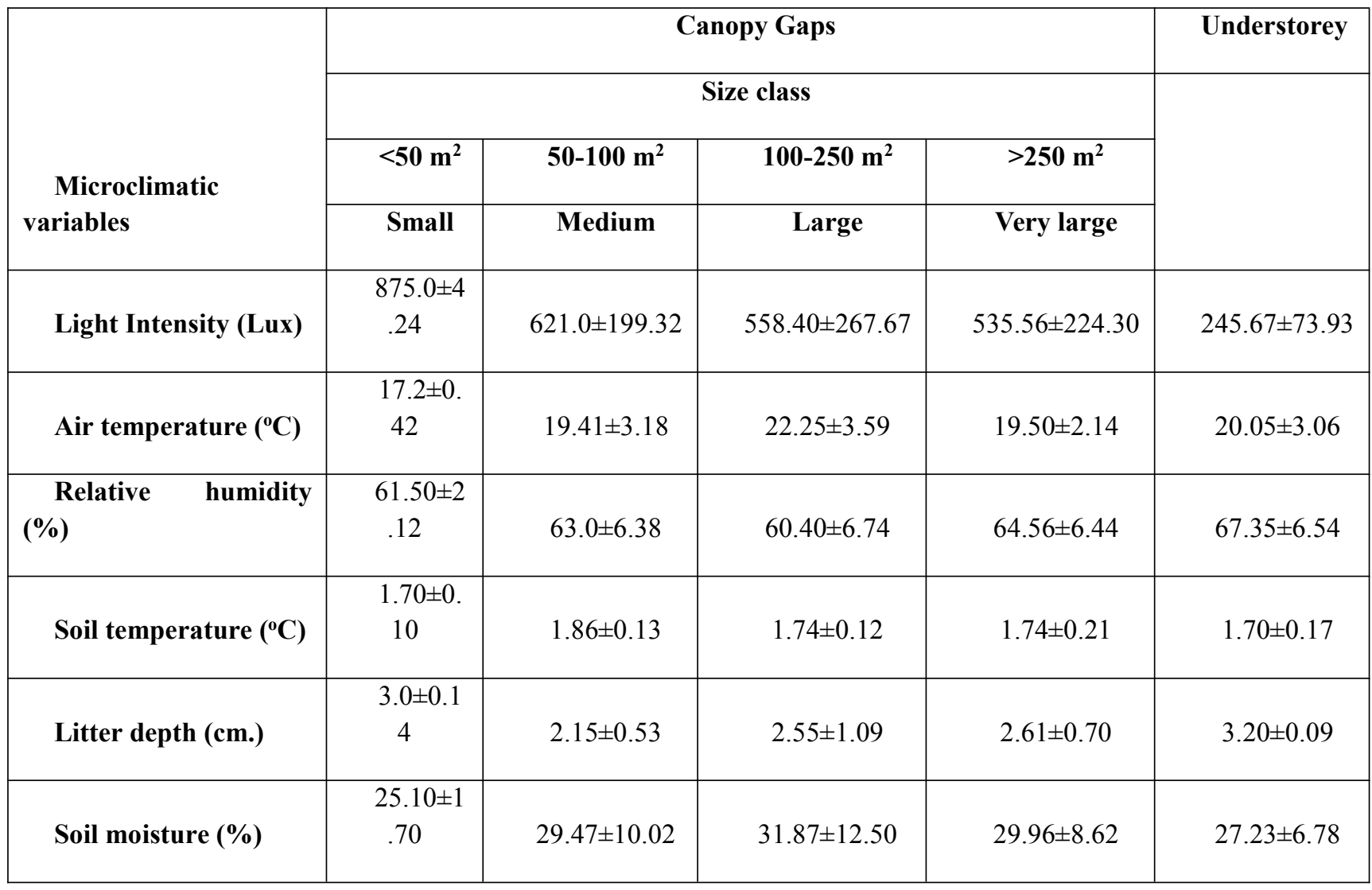

Table 2. Mean and standard deviation (mean \pm S.D.) of environmental variables in the gaps (in four different size classes) and understorey of the study area

of 400 seedlings ha ${ }^{-1}$ followed by Neolitsea pallens (306 seedlings ha ${ }^{-1}$ ) and Carpinus viminea (287 seedlings ha ${ }^{-1}$ ) contributed maximum to regeneration in the gaps. Quercus leucotrichophora as shade tolerant and a climax species found in the top layer of mixed broad leaved temperate forests recorded the highest regeneration with a density of 167 seedlings $\mathrm{ha}^{-1}$. Eleven tree species belonging to middle canopy of the forest were found regenerating in the gaps. Rhododendron arboreum, Neolitsea pallens, Carpinus viminea formed the constituent species. Three tree species of lower canopy layer viz. Cinnamomum tamala, Debregeasia salicifolia and Ficus nemoralis were also recorded from the gaps.

Understorey adjacent to each canopy gap area was also investigated for assessing tree species regeneration status. Only four top canopy species were found regenerating in the understorey. Alnus nepalensis a top canopy and pioneer for broad leaved forests, with a sapling density of 160 individuals ha ${ }^{-1}$ and seedling density of 206 individuals ha ${ }^{-1}$ was observed regenerating profusely in understory adjacent to canopy gaps. Rhododendron arboreum, Neolitsea pallens, Betula alnoides formed the constituent species of ten major mid canopy species regenerating in understory areas. Debregeasia salicifolia, C.tamala and Ficus nemoralis were lower canopy species found regenerating in the understorey. About 17 tree species regenerating in canopy gaps and adjacent understorey areas were found common, whereas 6 tree species were exclusively found regenerating in gaps and 3 in adjacent understorey (Table $\mathbf{3}$ ).

\subsection{Classification and ordination of gap and non gap area}

The main matrix for CCA study was gaps and tree species present in these gaps and second matrix was gaps and recorded microclimatic variables in these gaps. Number of canonical axis are 3 and total variance ("inertia") in the 
species data was calculated 7.31 for gaps and 4.35 for adjacent understory. The results of the Cluster (Sorenson (Bray-Curtis) and CCA showing relationship between gap characteristics and environmental variables are shown in the

\begin{tabular}{|c|c|c|c|c|c|c|}
\hline \multirow{2}{*}{\multicolumn{2}{|c|}{ Species }} & \multirow{3}{*}{$\begin{array}{c}\begin{array}{c}\text { Canopy } \\
\text { status }\end{array} \\
\text { Top }\end{array}$} & \multicolumn{4}{|c|}{ Density (individuals/ha) } \\
\hline & & & \multirow{2}{*}{$\begin{array}{c}\begin{array}{c}\text { Understorey } \\
\text { Sapling }\end{array} \\
159.84 \\
\end{array}$} & \multirow{2}{*}{\begin{tabular}{l|} 
Understory \\
Seedling
\end{tabular}} & $\begin{array}{l}\text { Seedling in } \\
\text { Gaps }\end{array}$ & \multirow{2}{*}{$\begin{array}{r}\text { Total } \\
366.3\end{array}$} \\
\hline 1 & Alnus nepalensis D.Don & & & & 0 & \\
\hline 2 & Aesculus indica Colebr. & Top & 0 & 0 & 13.22 & 13.22 \\
\hline 3 & $\begin{array}{l}\text { Fraxinus micrantha } \\
\text { Lingelsh. }\end{array}$ & Middle & 0 & 0 & 59.94 & 59.94 \\
\hline 4 & $\begin{array}{l}\text { Betula } \\
\text { Buch.-Ham. }\end{array}$ & Middle & 0 & 209.79 & 46.62 & $\begin{array}{c}256.4 \\
1\end{array}$ \\
\hline 5 & $\begin{array}{l}\text { Carpinus viminea } \\
\text { Lindle }\end{array}$ & Middle & 0 & 39.96 & 286.38 & $\begin{array}{c}326.3 \\
4\end{array}$ \\
\hline 6 & $\begin{array}{l}\text { Cinnamomum tamala } \\
\text { (Buch.-Ham.) Nees and } \\
\text { Ebermaeir }\end{array}$ & Lower & 0 & 6.66 & 399.6 & $\begin{array}{l}406.2 \\
6\end{array}$ \\
\hline 7 & $\begin{array}{l}\text { Cotoneaster affinis } \\
\text { Lindley var. bacillaris } \\
\text { (Lindley) Schneider }\end{array}$ & Lower & 0 & 0 & 33.3 & 33.3 \\
\hline 8 & $\begin{aligned} \text { Debregeasia } & \text { salicifolia } \\
\text { (D.Don)Rendle } & \end{aligned}$ & Lower & 23.31 & 83.25 & 13.32 & $\begin{array}{c}119.8 \\
8\end{array}$ \\
\hline 9 & Ficus nemoralis Wall & Lower & 0 & 43.29 & & 43.29 \\
\hline 10 & Ilex dipyrena Wall & Middle & 0 & 0 & 133.2 & 133.2 \\
\hline 11 & $\begin{array}{l}\text { Lindera pulcherrima } \\
\text { Benth. }\end{array}$ & Middle & 3.33 & 0 & 26.4 & 29.73 \\
\hline 12 & $\begin{array}{l}\text { Lyonia ovalifolia (Wall.) } \\
\text { Drude }\end{array}$ & Middle & 19.98 & 116.55 & 79.92 & $\begin{array}{l}216.4 \\
5\end{array}$ \\
\hline 13 & $\begin{array}{l}\text { Myrica esculenta } \\
\text { Buch.-Ham. Ex Don }\end{array}$ & Middle & 9.99 & 46.62 & 53.28 & $\begin{array}{l}109.8 \\
9\end{array}$ \\
\hline 14 & Neolitsea pallens Nees & Middle & 116.55 & 646.02 & 306.36 & $\begin{array}{l}1068 . \\
93\end{array}$ \\
\hline 15 & $\begin{array}{l}\text { Persea duthei (King ex } \\
\text { Hook.f.) }\end{array}$ & Middle & 0 & 0 & 13.32 & 13.32 \\
\hline 16 & Prunus cerasoides Don & Top & 0 & 6.66 & 13.32 & 19.98 \\
\hline 17 & $\begin{array}{cc}\text { Pyrus } & \text { pashia } \\
\text { Buch-Ham. } & \end{array}$ & Middle & 13.32 & 113.22 & 173.16 & 299.7 \\
\hline 18 & Quercus floribunda & Top & 7 & 0 & 6.66 & 6.66 \\
\hline
\end{tabular}




\begin{tabular}{|c|c|c|c|c|c|c|}
\hline & (Lindl.) Rehde & & & & & \\
\hline 19 & Quercus glauca Thunb. & Top & 0 & 13.32 & & 13.32 \\
\hline 20 & $\begin{array}{l}\text { Quercus } \\
\text { leucotrichophora A. } \\
\text { Camus }\end{array}$ & Top & 23.31 & 259.74 & 166.5 & $\begin{array}{l}449.5 \\
5\end{array}$ \\
\hline 21 & $\begin{array}{l}\text { Quercus semecarpifolia } \\
\text { Smith }\end{array}$ & Top & 0 & 0 & 33.3 & 33.3 \\
\hline 22 & $\begin{array}{l}\text { Rhododendron } \\
\text { arboreum Smith }\end{array}$ & Middle & 79.92 & 995.67 & 259.74 & $\begin{array}{l}1335 \\
33\end{array}$ \\
\hline 23 & $\begin{array}{l}\text { Symplococs paniculata } \\
\text { Buch-Ham. }\end{array}$ & Middle & 13.32 & 183.15 & 126.54 & $\begin{array}{c}323.0 \\
1\end{array}$ \\
\hline 24 & Unidentified & & 3.33 & 76.59 & 33.3 & $\begin{array}{l}113.2 \\
2\end{array}$ \\
\hline & Total & & 466.2 & 3046.95 & $\begin{array}{c}2277.3 \\
8\end{array}$ & $\begin{array}{l}5790 \\
53\end{array}$ \\
\hline
\end{tabular}

Table 3. Tree seedling regeneration status in the understorey and canopy gaps of the study area

ordination diagrams in Figure 2, 3. Significant climatic and edaphic variables recorded in the study area where laid as correlation vectors on the ordination plot; the length and direction of the vector represented the relative importance of the micro climatic variables to the CCA axis. The canonical ordination axis 1 explained $9 \%$ of cumulative variance, second axis explained $15.4 \%$ and axis 3 explained $20.5 \%$ of cumulative variance. Overall $44.9 \%$ of cumulative variance was explained in species data and their environment relationships (Table 4). Cluster analysis of the gap areas differentiated them into five major groups that differed in their species composition and regeneration pattern and were influenced by environmental and microclimate variables. Result of CA indicates that group 3 and group 5 are somewhat different than other group of gaps but for present paper we have not followed this difference with further statistical analysis. CCA of the study site shows that soil moisture $(\%)$, soil temperature $\left({ }^{\circ} \mathrm{C}\right)$, light intensity (Lux) and air temperature $\left({ }^{\circ} \mathrm{C}\right)$ are the prime variables for the segregation of the group of gaps based on the regeneration pattern of tree species (Figure 2). Soil moisture was found positively correlated while; both soil temperature and air temperature were negatively correlated with the first axis of CCA. Air temperature was positively correlated and soil moisture was negatively correlated with the second axis of CCA. Light intensity was found negatively correlated with both first and second axis of CCA $(P \leqslant 0.1)$. Based on the analyses CCA clearly distinguished five major groups of canopy gaps differentiated by cluster analysis as indicated by the distinct separation of the gaps along the two CCA axis (Figure 2). 


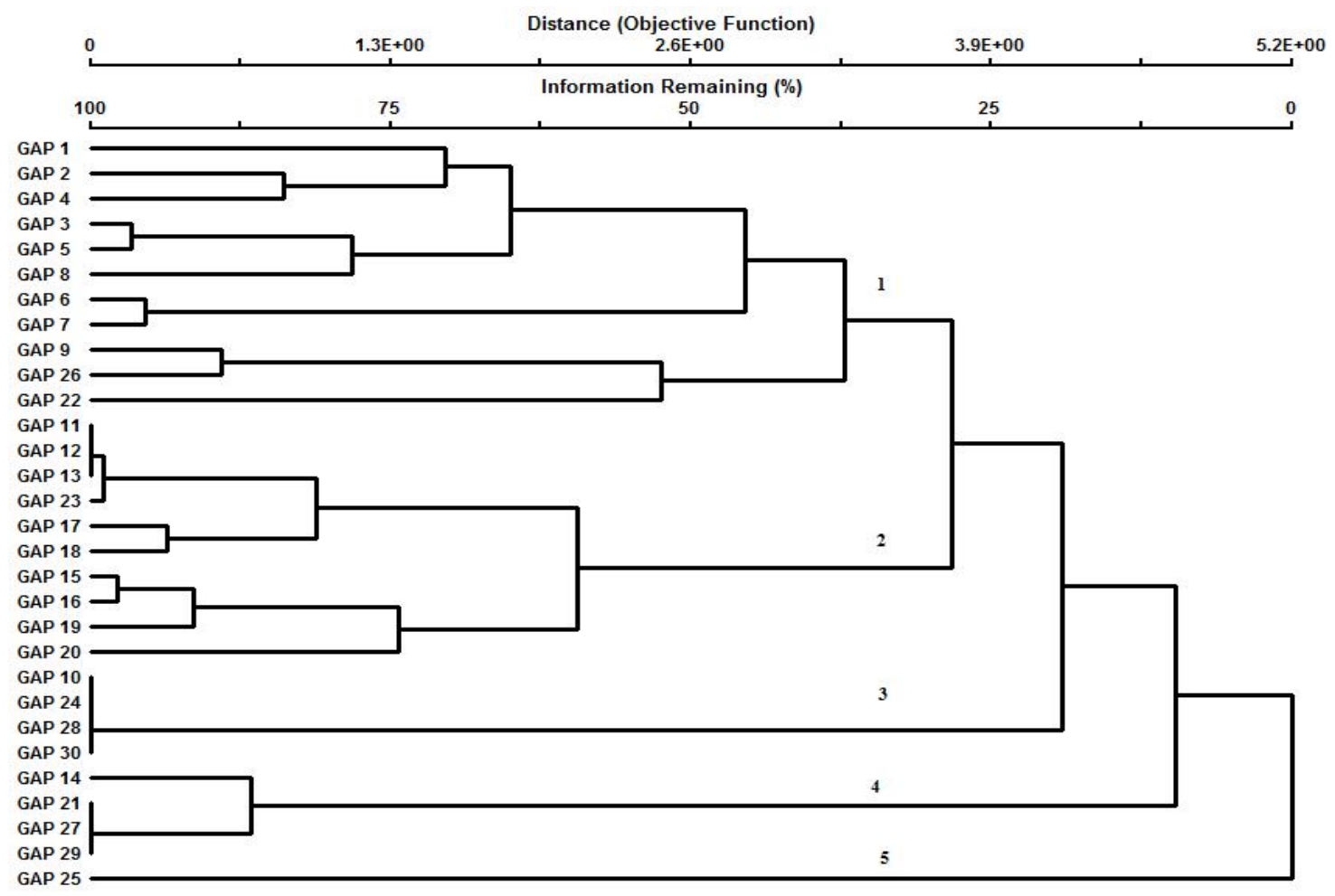

Sorenson (Bray-Curtis) and Group average

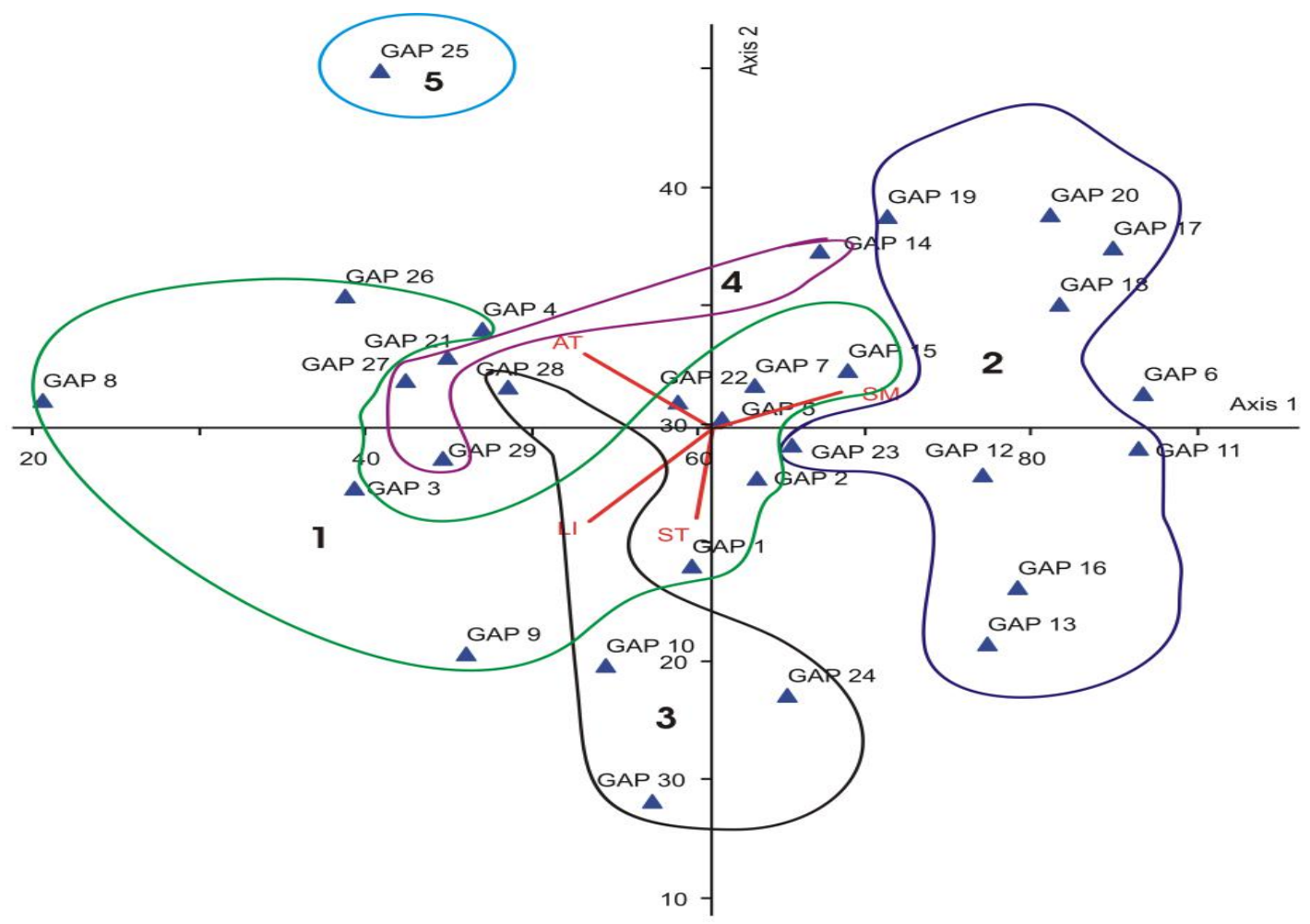

Figure 2; Cluster and Canonical correspondence analysis (CCA) diagram for the gap areas and environmental variables (red lines) (AT=Air temperature; $\mathrm{SM}=$ soil moisture; $\mathrm{LI}=$ Light Intensity; $\mathrm{ST}=$ Soil Temperature). 


\begin{tabular}{|l|c|c|c|}
\hline Parameters & Axis 1 & Axis 2 & Axis 3 \\
\hline Eigen value & 0.661 & 0.465 & 0.370 \\
\hline Variance in species data & & & \\
\hline Percent of variance explained & 9.0 & 6.4 & 5.1 \\
\hline Cumulative percent explained & 9.0 & 15.4 & 20.5 \\
\hline Pearson Correlation,* & 0.890 & 0.776 & 0.757 \\
\hline Kendall (Rank) Correlation & 0.697 & 0.636 & 0.571 \\
\hline
\end{tabular}

* Correlation between sample scores for an axis derived from the species data and the sample scores that are linear combinations of the environmental variables.

Table 4. Axis summary statistics for CCA percentage variance explained by 3 canonical CCA axis for canopy gaps in the study area

Cluster analysis of the understorey adjacent to gaps differentiated them into five major groups that differed in their species composition and regeneration pattern which was influenced with micro-environmental and other variables (Figure 3). In canonical ordination of understorey areas axis 1 explained $14.6 \%$, axis 2 explained $26.3 \%$ and axis 3 explained $32.2 \%$ of cumulative variance and overall $73.1 \%$ of variables explained species data and their environment relationships in forest understorey adjacent to canopy gaps (Table 5).

\begin{tabular}{|l|c|c|c|}
\hline Parameters & Axis 1 & Axis 2 & Axis 3 \\
\hline Eigen value & 0.634 & 0.511 & 0.257 \\
\hline Variance in species data & & & \\
\hline $\begin{array}{l}\text { Percent of variance } \\
\text { explained }\end{array}$ & 14.6 & 11.7 & 5.9 \\
\hline $\begin{array}{l}\text { Cumulative percent } \\
\text { explained }\end{array}$ & 14.6 & 26.3 & 32.2 \\
\hline $\begin{array}{l}\text { Pearson Correlation,* } \\
\text { Kendall (Rank) } \\
\text { Correlation }\end{array}$ & 0.876 & 0.823 & 0.640 \\
\hline
\end{tabular}

Table 5. Axis summary statistics for CCA percentage variance explained by 3 canonical CCA axes for forest understorey in the study area

CCA analyses of the understorey sites showed that total basal area $\left(\mathrm{m}^{2} \mathrm{ha}^{-1}\right)$, air temperature $\left({ }^{\circ} \mathrm{C}\right)$, soil temperature $\left({ }^{\circ} \mathrm{C}\right)$, density of saplings and seedlings, light intensity (Lux), litter thickness $(\mathrm{cm})$ and relative humidity $(\%)$ are the prime variables of segregation in regeneration pattern in non gap areas of adjacent understorey (Figure 3 ). In the analyses air temperature, light intensity, sapling density, seedling density and soil temperature showed strong positive correlation with second axis of CCA while, both relative humidity and litter thickness showed strong negative correlation with the first axis of CCA. In the analyses total basal area of trees showed strong negative correlation with the first axis of CCA. Air temperature was found positively correlated with the second axis of CCA. Light intensity was also negatively correlated with both first and second axis of CCA at $(\mathrm{P} \leq 0.1)$. The understorey of adjacent intact forest areas in close geographic proximity grouped together indicating that they shared a more similar species composition.

\section{Discussion}

\subsection{Gap disturbance Patterns}

In spite of the heterogeneity of responses, some patterns of the behavior of regeneration could be identified in the 
vegetation in response to the gap physical characteristics that results from the specific disturbance in the openings of these gaps. In the forests of the study area gaps are created by tree falls and death of standing trees due to insects, diseases (mainly in Quercus leucotricophora) and winds. Heavy rainfall predominant throughout the year along with heavy snowfall during winters is a major cause of gap formation in forests of the area. A single or multi-tree gap may initiate a new period of recruitment depending on the presence of seed or advance reproduction and the degree to which site resources are released (Brokaw 1982). Even though, gap size class distribution in the study site was similar to those reported in other studies, the number of gaps per hectare and percent gap area was high compared to other studies (Hubbell and Foster 1986; Sanford et al. 1986; Kern et al. 2013). Canopy gap of small gap sizes are common in mixed broadleaved forests of the study area hence, gaps $\leq 25 \mathrm{~m}^{2}$ were not considered for our study and such exclusions of small gaps is also recommended (Runkle 1990; Yamamoto 2000). It was also observed that gaps with more light intensity had substantially more species than in non gap mature forest sites. CCA analysis shows that in understorey areas air temperature, light intensity, density of sapling and seedlings and soil temperature have a cumulative effect on regeneration of tree species (Figure3). Litter depth is an important variable that controls tree species regeneration in understory areas of the forest. Survival of small seeds is intricate in increased litter depth on forest floor. The period and intensity of light received by a gap seems related not only to its size, but also to other characteristics, such as shape, exposition, terrain inclination, height of surrounding vegetation and surviving vegetation after tree fall. Thus, the increase in gap size also increases environmental heterogeneity in the interior of these gaps.

\subsection{Gap colonization}

The data on the tree regeneration in gaps and understorey areas showed that both areas exhibited high species diversity and density, though it differed from the species composition of the tree stratum. In the present study the juvenile composition also varied from stand to stand at different locations of the studied forest patches. The changes in species composition among the stands may be due to topography, altitude and edaphic factors. The higher species richness for sapling layer in the understorey areas could be attributed to the fact that many species exists in forest understorey in suppressed condition until favourable environment, which then helped them to grow to the canopy level.

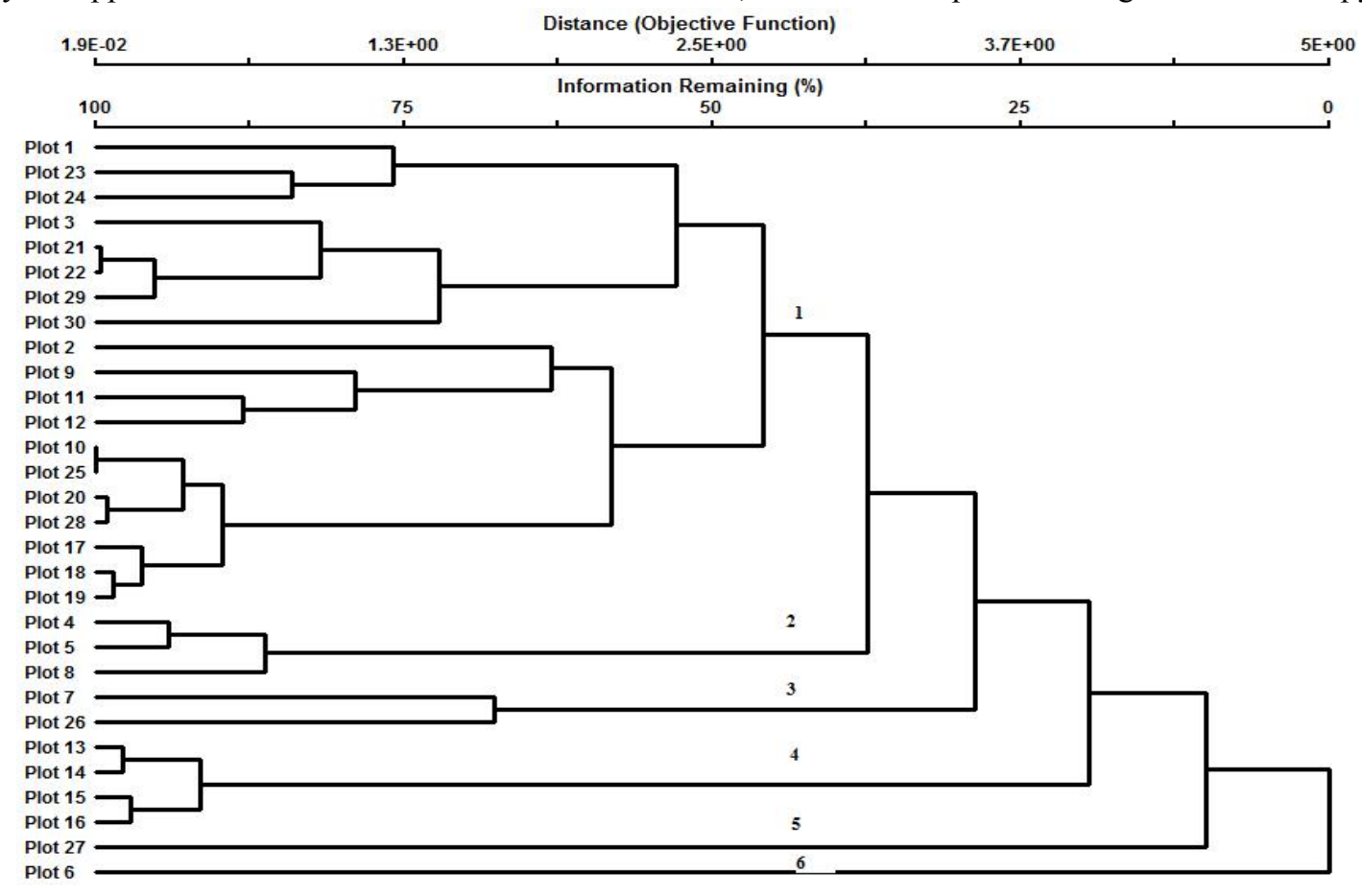

Sorenson (Bray-Curtis) and Group average 


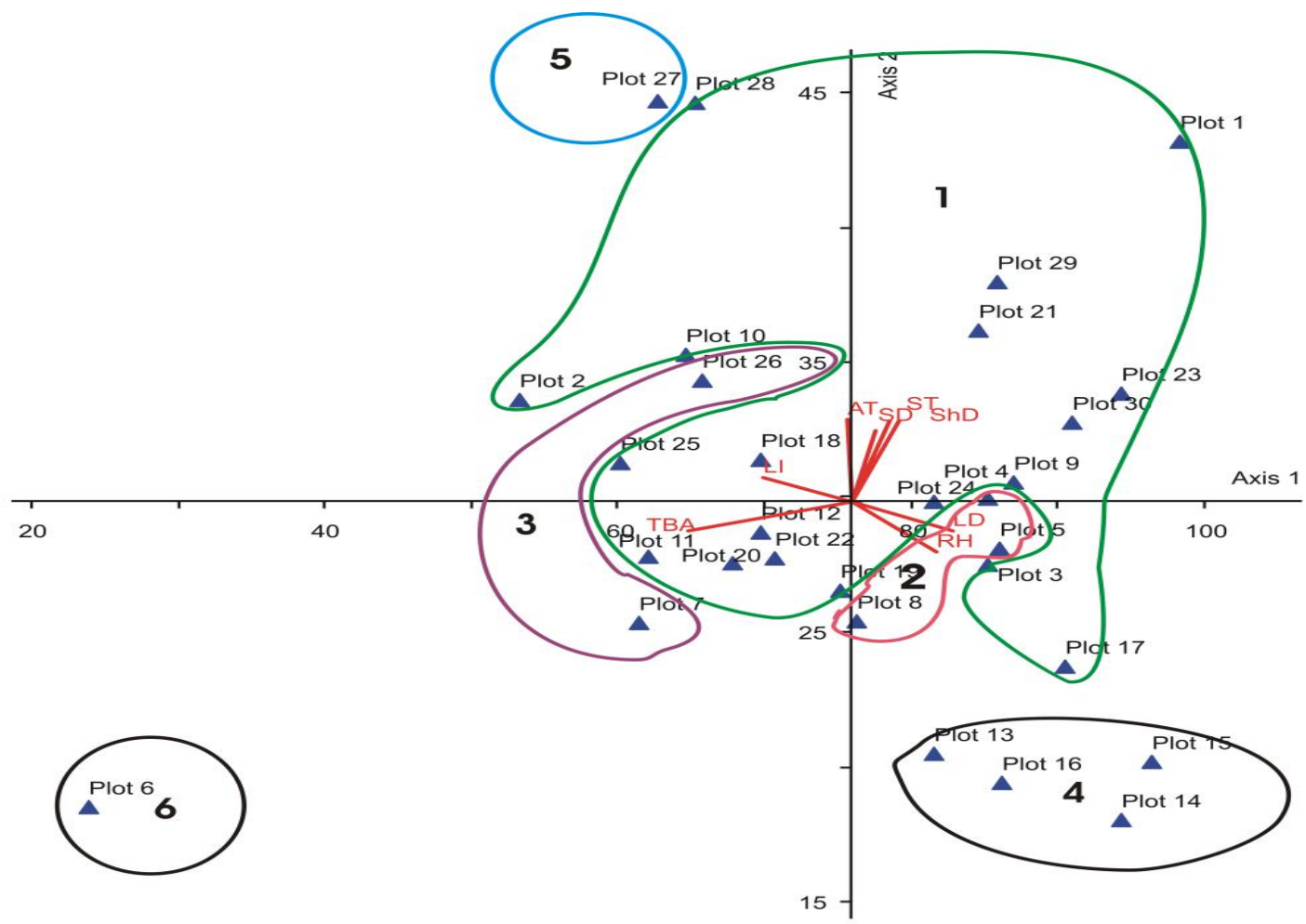

Figure 3; Cluster and Canonical correspondence analysis (CCA) diagram for the adjacent understory and environmental variables (red lines) ( $\mathrm{LI}=\mathrm{Light}$ intensity; $\mathrm{AT}=\mathrm{Air}$ temperature; $\mathrm{SD}=\mathrm{Sapling}$ density; $\mathrm{ST}=\mathrm{Soil}$ temperature; $\mathrm{ShD}=\mathrm{Shrub}$ density; TBA=Total basal area; RH=Relative humidity; LD=Litter depth).

The marked difference in species composition in gaps showed that the plant species behaviour in gaps is perhaps independent of gap size and their presence is mainly governed by availability of seeds in forest germinable soil seed bank at the time of creation of gaps. Maximum contribution to regeneration was from mid and lower canopy species (Neolitsea pallens, Symplocos paniculata, Cinnamomum tamala etc.), which are better adapted to grow in shady conditions. The poor status of pioneers (Alnus nepalensis) could be attributed to the small sizes of gaps. The paucity of seedlings of Alnus nepalensis as pioneer as witnessed in the gaps of the present study area may be attributed to its small seed size. Cotoneaster affinis, Ilex dipyrena, Quercus floribunda and Quercus semecarpifolia seedlings were recorded only in gaps and not in understory during our study. Even gaps differed in species composition in this investigation, which could be attributed to different location of the gap and their small size that could accommodate only a few species. Pattern of floristic changes in gaps and nearby areas is affected by proximity of potential seed sources and presence of advance regeneration at the time of disturbance or creation of gap (Lieberman 1996). Gaps in close geographic proximity grouped together indicating that they shared similar species composition.

\subsection{Microclimatic variations}

The difference in species composition between gaps and understorey may be attributed to micro-environmental variations at gaps and understorey. Most of the gaps encountered in the study area were not very big in size but 9 gaps were $>250 \mathrm{~m}^{2}$ of size. The understorey locations showed more litter depth, low soil temperature and higher moisture content. Soil temperature in gaps was more influenced by litter depth than by solar radiation, and no sudden air temperature change was recorded in gaps. The variations in microclimatic conditions between gaps and close-canopy will not be sharp if gaps were of small sizes, however, with increase in gap sizes the extreme values of microclimate may change markedly (Whitmore 1996). There were clear differences in canopy gap dynamics and understorey light availability between the primary and regenerating forest stands. Differences in levels of light in large and medium sized gaps compared to forest understory allow the recruitment of light intolerant or less tolerant species. In small sized gaps change in the light environment was not sufficient to lead differences in species recruitment. Microclimatic variations due to presence or absence of tree canopy are important, to create changes in the regeneration structure of the forests. 
The influence of topography on soil and climate conditions promotes environment conditions are different enough to influence species performance and distribution. This explains the differences in temperature between gaps and non-gaps in the present study. Variations were observed in microclimatic parameters recorded from canopy gap and adjacent understorey areas of the study area though, at a very low level $(r<0.2)$. The division of forest into gaps and the understorey of adjacent intact forest areas were not sharp though increasing gap size resulted in greater variation in microclimatic parameters. Seedlings of many shade tolerant species were found to have similar tendency to establish in gaps as well as close canopy forests. The data suggests that even in one forest, gaps has different regenerating species due to the influence of estimated microclimatic variations such as soil moisture, soil type, soil nutrients, temperature coupled with many non estimated variations such as exposure, insulation and wind. Light intensity was negatively correlated with both first and second axis of CCA this reflects that for canopy gaps light intensity was not a strong microclimatic variable. While, other studies have reported that, air temperature and light intensity were the dominant gradients underlying regional differences in the regenerating species composition and abundance among gaps (Latif and Blackburn 2010). CCA for canopy gaps reflected soil moisture as an important microclimatic variable that has influenced regeneration in canopy gaps. Regression models and ordinations may provide some insights into factors and variables that influence species abundance and composition in gaps. But these models and ordinations are majorly based on a limited suite of measurements that are correlative in nature. Much of our gap research was focused on impacts of gap formation on above ground processes, especially vegetation growth. Our knowledge of below ground responses remains weak. Future research focused on below ground processes, including biogeochemistry, microbial growth and composition and soil characteristics, would greatly further the overall understanding of gap dynamics and their impact on forest as a whole. In general, the unique microclimate of gaps-increased soil temperature, increased soil moisture and increased solar radiation- is known to influence nutrient cycling and microbial dynamics. However, more research is needed to truly understand how belowground processes are impacted by many gap characteristics including gap size, shape, age and cover type. The creation of gaps in the canopy results in a sudden increase in light, and the ability to take advantage of these sites is vital for the maintenance of light demanding species. The capacity to occupy these sites is related to the degree of plasticity displayed in response to changes in light (and also other resources such as nutrients and water, which are not mentioned). However, in natural gaps the advanced regeneration (seedlings established in the understorey before gap creation) dominates the re-growth, which consists mainly of non-pioneer species. In some cases the canopy opening is desirable in order to promote the regeneration of pioneers of commercial interest. With respect to tree species composition there is not much difference in canopy gaps and forest understorey. There is not a very expressive variation of tree species regenerating in canopy gaps and forest understorey of the study area. Most abundant and species-rich families of trees are more or less similar in gaps and understorey. Besides, the physical and structural gap characteristics analysed, others such as gap opening time, geographic orientation, micro-sites formed by litterfall, degradation of the surrounding vegetation and the presence of remaining shrubs and trees, must also influence the colonizing vegetation parameters.

\section{Conclusions}

Our results suggest that colonization via pre-established individuals can be the prominent strategy to colonize gaps, approximating community composition of gap and the understorey of adjacent intact forest areas as also observed elsewhere. The results of this study indicate that the relationship between the canopy gap characteristics and regeneration of tree species is very complex especially for moist temperate forests of Garhwal. As these forests are also source of subsistence life support and are also been source of many valuable medicinal and aromatic plants. Gaps do promote tree diversity, but mainly by increasing community-wide seedling establishment. Creation of gaps is an essential component for maintaining tree diversity of the forest stand in mixed broad leaved forests of Garhwal. This study has been a priliminary study from Watern Himalays hence it is, however, suggested that there is a further need to study survival pattern of the species in the gaps immediately after its formation so that the successional pattern of the 
forest could be analyzed and predicted. The comprehension of the factors that rule the gaps colonization is vital for the definition of strategies aiming at the maintenance of temperate forest fragments and restoration of areas already degraded.

\section{Acknowledgements}

Authors wish to thank the Directors, CSIR-NEERI, Nagpur the current workplace of corresponding author and GBPIHED, Kosi-Katarmal, Almora where the work was carried out for providing necessary facilities. Authors are grateful to Dr. Man Singh for providing necessary suggestions in statistical analysis. Financial support for the fieldwork from Tropical Soil Biodiversity and Fertility Programme (TSBF)/Global Environment Facility (GEF) and current support from DST SYSP Scheme (SP/YO/024/2008), New Delhi, India is highly acknowledged.

\section{Conflict of Interest Statement}

The authors declare that the research was conducted in the absence of any commercial or financial relationships that could be construed as a potential conflict of interest. Authors also declare that they don't have any competing interests.

\section{References}

1. Alvarez-Buylla, ER, Garci'a-Barrios R. 1991. Seed and forest dynamics: a theoretical framework and an example from the neotropics. American Naturalist 137:133-154.

2. Braker HE, Chazdon RL. 1992. Ecological, behavioral, and nutritional factors influencing use of palms as host plants by a Neotropical forest grasshopper. Journal of Tropical Ecology 9:181-195.

3. Brokaw NVL. 1982 a. The definition of tree fall gaps and its effect on measures of forest dynamics. Biotropica 11: $158-60$.

4. Brokaw NVL. 1985. Gap phase regeneration in a tropical forest. Ecology 66: 682-687.

5. Brokaw NVL.1985. Treefalls, regrowth, and community structure in Tropical forests. Pages 53-69 In: S. T. A. Pickett and P. S. White, editors. The ecology of natural disturbance and patch dynamics. Academic Press, San Diego, California, USA.

6. Brokaw N, Busing RT. 2000. Niche versus chance and tree diversity in forest gaps. Trends in Ecology and Evolution 15:183-188.

7. Chazdon RL, Fetcher N. 984. Photosynthetic light environments in a lowland tropical rain forest in Costa Rica. Journal of Ecology 72:553-564.

8. Coates KD. 2000. Conifer seedling response to northern temperate forest gaps. Forest Ecology and Management 127: 249-269.

9. Deb Panna, Sundriyal RC. 2007. Tree species gap phase performance in the buffer zone area of Namdapha National Park, Eastern Himalaya, India. Tropical Ecology 48: 209-225.

10. Denslow JS. 1987. Tropical rainforest gaps and tree species diversity. Annual review of Ecological Systems 18: 431-451.

11. Dinerstein, E. 1997. A Framework for identifying high Priority Areas and Actions for Conservation of Tiger in the Wild. WWF, WCS, NFWF.

12. Henle K, Davies KF, Kleyer M, Margules C, Settele J. 2004a. Predictors of species sensitivity to fragmentation. Biodiversity and Conservation 13: 207-251.

13. Hubbell SP, Foster RB. 1986. Biology, chance and history and the structure of tropical rainforest tree communities. In: Community Ecology. Diamond J, Case TJ (Eds.), Harper and Row, New York. pp. 314-29.

14. Kern CC, Montgomery RA, Reich PB, Strong TF. 2013. Canopy gap size influences niche partitioning of the ground-layer plant community in a northern temperate forest Journal of Plant Ecology 6: 101-112.

15. Latif ZA, Blackburn GA. 2010. The effects of gap size on some microclimate variables during late summer and autumn in a temperate broadleaved deciduous forest. International Journal of Biometerology 54:119-129

16. Lieberman D, Liberman M, Peralta R, Harshorn GS, 1996. Tropical forest structure and composition on a large-scale altitudinal gradient in Costa Rica. Journal of Ecology 84: 137-152.

17. Lima RAF. 2005. Gap size measurement: The proposal of a new field method. Forest Ecology and Management 214: 413-419.

18. Major KC, Nosko P, Kuehne C, Campbell D, Bauhus J. 2013. Regeneration dynamics of non-native northern red oak (Quercus rubra L.) populations as influenced by environmental factors: A case study in managed hardwood forests of southwestern Germany. Forest Ecology and Management 291: 144-153.

19. McCarthy J. 2001. Gap dynamics of forest trees: A review with particular attention to boreal forests. Environmental Review 9: 1-59.

20. McCune B, Mefford MJ. 1999. PC-ORD: Multivariate analysis of ecological data. Version 4. MjM Software 
Design, Gleneden Beach; OR.

21. Misra S. 2009. Impact of natural and man-made disturbances on vegetation structure and diversity in Guptakashi range of Kedarnath Forest Division, Uttarakhand. Ph.D. Thesis, Forest Research Institute.

22. Murray KG. 1988. Avian seed dispersal of three neotropical gap-dependent plants. Ecological Monographs 58:271-298.

23. Oliver CD, Larson BC. 1996. Forest Stand Dynamics, update edition. Mc Graw-Hill Book Company, New York.

24. Ou Y, Su Z. 2012. Dynamics of canopy structure and understory light in montane evergreen broadleaved forest following a natural disturbance in North Guangdong. Shengtai Xuebao/ Acta Ecologica Sinica 32 (18), pp. 5637-5645.

25. Pielou EC 1984. The interpretation of ecological data: a primer on classification and ordination. John Wiley and Sons, New York. pp. 263.

26. Prabhakar R, Somanathan E, Singh Mehta B. 2006. How degraded are Himalayan forests? Current Science 91: 61-67.

27. Runkle, J. R. 1982. Patterns of disturbance in some old-growth mesic forests of eastern North America. Ecology 63(5): 1533-1546.

28. Runkle JR 1990. Gap dynamics in an Ohio Acer-Fagus forest and speculations on the geography of disturbance. Canadian Journal of Forest Research 20: 632-641.

29. Sanford RL, Braker HE, Hartshorn GS. 1986. Canopy openings in a primary Neotropical lowland forest. Journal of Tropical Ecology 2: 277-282.

30. Misra S, Maikhuri RK, Dhyani D, Rao KS. 2009. Assessment of traditional rights, local interferences and natural resource management issues in Garhwal part of Indian Himalayan Region. International Journal of Sustainable development and World Ecology 16: 404-416

31. Slik JWF, Kebler PJA, van Welzen PC. 2003. Macaranga and Mallotus species (Euphorbiaceae) as indicators for disturbance in the mixed lowland dipterocarp forest of East Kalimantan (Indonesia). Ecological Indicators 2: 311-324.

32. Ter Braak CJF. 1987. The analysis of vegetation-environment relations by canonical correspondence analysis. Vegetatio 69: 69-77.

33. Uhl C, Clark K, Dezzeo N, Maquirrino P. 1988. Vegetation dynamics in Amazonian treefall gaps. Ecology 69:751-763.

34. Veihmeyer FJ, Hendrickson AH. 1931. The moisture equivalent as a measure of field capacity of soils. Soil Science 32: 181-194.

35. Whitmore TC. 1996. A review of some aspects of tropical rainforest seedling ecology with suggestions for further enquiry. In: Ecology of Tropical Forest Tree Seedlings, Swaine, M.D. (Eds.). UNESCO/Parthenon, Paris/Canforth. pp. 3-39.

36. Yamamoto S. 1995. Gap characteristics and gap regeneration in a subalpine old-growth Coniferous forests, Central Japan. Ecological Research (Tokyo) 10: 31-39.

37. Yamamoto S. 2000. Forest gap dynamics and tree regeneration. Journal of Forest Research 5: 223-229.

38. Alvarez-Buylla, ER, Garc1'a-Barrios R. 1991. Seed and forest dynamics: a theoretical framework and an example from the neotropics. American Naturalist 137:133-154.

39. Braker HE, Chazdon RL. 1992. Ecological, behavioral, and nutritional factors influencing use of palms as host plants by a Neotropical forest grasshopper. Journal of Tropical Ecology 9:181-195.

40. Brokaw NVL. 1982 a. The definition of tree fall gaps and its effect on measures of forest dynamics. Biotropica 11: $158-60$.

41. Brokaw NVL. 1985. Gap phase regeneration in a tropical forest. Ecology 66: 682-687.

42. Brokaw NVL. 1985. Treefalls, regrowth, and community structure in Tropical forests. Pages 53-69 In: S. T. A. Pickett and P. S. White, editors. The ecology of natural disturbance and patch dynamics. Academic Press, San Diego, California, USA.

43. Brokaw N, Busing RT. 2000. Niche versus chance and tree diversity in forest gaps. Trends in Ecology and Evolution 15:183-188.

44. Chazdon RL, Fetcher N. 984. Photosynthetic light environments in a lowland tropical rain forest in Costa Rica. Journal of Ecology 72:553-564.

45. Coates KD. 2000. Conifer seedling response to northern temperate forest gaps. Forest Ecology and Management 127: 249-269.

46. Deb Panna, Sundriyal RC. 2007. Tree species gap phase performance in the buffer zone area of Namdapha National Park, Eastern Himalaya, India. Tropical Ecology 48: 209-225.

47. Denslow JS. 1987. Tropical rainforest gaps and tree species diversity. Annual review of Ecological Systems 18: 431-451.

48. Dinerstein, E. 1997. A Framework for identifying high Priority Areas and Actions for Conservation of Tiger in the 
Wild. WWF, WCS, NFWF.

49. Henle K, Davies KF, Kleyer M, Margules C, Settele J. 2004a. Predictors of species sensitivity to fragmentation. Biodiversity and Conservation 13: 207-251.

50. Hubbell SP, Foster RB. 1986. Biology, chance and history and the structure of tropical rainforest tree communities. In: Community Ecology. Diamond J, Case TJ (Eds.), Harper and Row, New York. pp. 314-29.

51. Kern CC, Montgomery RA, Reich PB, Strong TF. 2013. Canopy gap size influences niche partitioning of the ground-layer plant community in a northern temperate forest Journal of Plant Ecology 6: 101-112.

52. Latif ZA, Blackburn GA. 2010. The effects of gap size on some microclimate variables during late summer and autumn in a temperate broadleaved deciduous forest. International Journal of Biometerology 54:119-129

53. Lieberman D, Liberman M, Peralta R, Harshorn GS, 1996. Tropical forest structure and composition on a large-scale altitudinal gradient in Costa Rica. Journal of Ecology 84: 137-152.

54. Lima RAF. 2005. Gap size measurement: The proposal of a new field method. Forest Ecology and Management 214: 413-419.

55. Major KC, Nosko P, Kuehne C, Campbell D, Bauhus J. 2013. Regeneration dynamics of non-native northern red oak (Quercus rubra L.) populations as influenced by environmental factors: A case study in managed hardwood forests of southwestern Germany. Forest Ecology and Management 291: 144-153.

56. McCarthy J. 2001. Gap dynamics of forest trees: A review with particular attention to boreal forests. Environmental Review 9: 1-59.

57. McCune B, Mefford MJ. 1999. PC-ORD: Multivariate analysis of ecological data. Version 4. MjM Software Design, Gleneden Beach; OR.

58. Misra S. 2009. Impact of natural and man-made disturbances on vegetation structure and diversity in Guptakashi range of Kedarnath Forest Division, Uttarakhand. Ph.D. Thesis, Forest Research Institute.

59. Murray KG. 1988. Avian seed dispersal of three neotropical gap-dependent plants. Ecological Monographs 58:271-298.

60. Oliver CD, Larson BC. 1996. Forest Stand Dynamics, update edition. Mc Graw-Hill Book Company, New York.

61. Ou Y, Su Z. 2012. Dynamics of canopy structure and understory light in montane evergreen broadleaved forest following a natural disturbance in North Guangdong. Shengtai Xuebao/ Acta Ecologica Sinica 32 (18), pp. 5637-5645.

62. Pielou EC 1984. The interpretation of ecological data: a primer on classification and ordination. John Wiley and Sons, New York. pp. 263.

63. Prabhakar R, Somanathan E, Singh Mehta B. 2006. How degraded are Himalayan forests? Current Science 91: 61-67.

64. Runkle, J. R. 1982. Patterns of disturbance in some old-growth mesic forests of eastern North America. Ecology 63(5): 1533-1546.

65. Runkle JR 1990. Gap dynamics in an Ohio Acer-Fagus forest and speculations on the geography of disturbance. Canadian Journal of Forest Research 20: 632-641.

66. Sanford RL, Braker HE, Hartshorn GS. 1986. Canopy openings in a primary Neotropical lowland forest. Journal of Tropical Ecology 2: 277-282.

67. Misra S, Maikhuri RK, Dhyani D, Rao KS. 2009. Assessment of traditional rights, local interferences and natural resource management issues in Garhwal part of Indian Himalayan Region. International Journal of Sustainable development and World Ecology 16: 404-416

68. Slik JWF, Kebler PJA, van Welzen PC. 2003. Macaranga and Mallotus species (Euphorbiaceae) as indicators for disturbance in the mixed lowland dipterocarp forest of East Kalimantan (Indonesia). Ecological Indicators 2: 311-324.

69. Ter Braak CJF. 1987. The analysis of vegetation-environment relations by canonical correspondence analysis. Vegetatio 69: 69-77.

70. Uhl C, Clark K, Dezzeo N, Maquirrino P. 1988. Vegetation dynamics in Amazonian treefall gaps. Ecology 69:751-763.

71. Veihmeyer FJ, Hendrickson AH. 1931. The moisture equivalent as a measure of field capacity of soils. Soil Science 32: 181-194.

72. Whitmore TC. 1996. A review of some aspects of tropical rainforest seedling ecology with suggestions for further enquiry. In: Ecology of Tropical Forest Tree Seedlings, Swaine, M.D. (Eds.). UNESCO/Parthenon, Paris/Canforth. pp. 3-39.

73. Yamamoto S. 1995. Gap characteristics and gap regeneration in a subalpine old-growth Coniferous forests, Central Japan. Ecological Research (Tokyo) 10: 31-39.

74. Yamamoto S. 2000. Forest gap dynamics and tree regeneration. Journal of Forest Research 5: 223-229. 